Clearly, multiple sclerosis plaques may mimic gliomas on computed tomography. Absence of a mass effect has been suggested as a diagnostic criterion for demyelination, ${ }^{5}$ but confusion may still occur. Doubts about the nature of such a lesion may be resolved by either biopsy or serial computed tomography.

${ }^{1}$ Currie S, Urich $\mathrm{H}$. Concurrence of multiple sclerosis and glioma. $\mathcal{f}$ Neurol Neurosurg Psychiatry 1974;37:598-605.

${ }^{2}$ Cala LA, Mastaglia FL, Black JL. Computerised tomography of brain and optic nerve in multiple sclerosis. Observations in 100 patients including serial studies in 16. Fournal of the Neurological Sciences 1978; 36:411-26.

${ }^{3}$ Van der Velden M, Bots GTAM, Endtz LJ. Cranial CT in multiple sclerosis showing a mass effect. Surg Neurol 1979;12:307-10.

4 Nelson MJ, Miller SL, McLain LW, Gold LHA. Multiple sclerosis: large plaque causing mass effect and ring sign. $\mathcal{F}$ Comput Assist Tomogr $1981 ; 5: 892-4$.

${ }^{5}$ Sears ES, Tindall RSA, Zarnow H. Active multiple sclerosis. Enhanced computerised tomographic imaging of lesions and the effect of corticosteroids. Arch Neurol 1978;35:426-34.

(Accepted 2 September 1982)

Department of Neurology, St James's University Hospital, Leeds LS9 7TF

R J ABBOTT, MB, MRCP, senior registrar

J G HOWE, MB, MRCP, tutor

S CURRIE, MD, FRCP, consultant

I HOLLAND, MB, FRCR, consultant neuroradiologist

\section{Renal artery thrombosis caused by antihypertensive treatment}

Antihypertensive drugs must be used cautiously in older patients. We describe an elderly man with Leriche's syndrome who developed anuria due to renal artery thrombosis after his blood pressure was reduced by atenolol. We believe that this complication of antihypertensive treatment has not been previously reported. ${ }^{1}$

\section{Case report}

A 70 -year-old man was admitted to hospital on 21 November 1981 with a three-day history of anuria. An inferior myocardial infarction had occurred in 1968. He had had mild intermittent claudication since 1971. In 1972 translumbar aortography had shown blockage of the left external iliac and right femoropopliteal arteries with good collateral circulation. The state of the renal arteries had not been noted. Mild hypertension had been treated with cyclopenthiazide $0.5 \mathrm{mg}$ daily for two years.

He had been given atenolol $100 \mathrm{mg}$ on 18 November because his blood pressure was $240 / 115 \mathrm{~mm} \mathrm{Hg}$. Five hours after the first dose he had become faint and his blood pressure was $130 / 70 \mathrm{~mm} \mathrm{Hg}$. He was admitted to hospital three days later having been completely anuric since taking the single atenolol tablet; his general condition was good and there was no evidence of acute myocardial infarction. Blood pressure was $160 / 80 \mathrm{~mm} \mathrm{Hg}$. Femoral pulses were impalpable but blood supply to the legs was satisfactory. Blood urea concentration was $19 \mathrm{mmol} / 1(114 \mathrm{mg} / 100 \mathrm{ml})$. When urine was passed after seven days the sodium content was $6-12 \mathrm{mmol}(\mathrm{mEq}) / \mathrm{l}$.

Intravenous urography and sonography showed a normal-sized right and a small left kidney without obstruction. No renal uptake occurred on scanning with technetium diethylene triamine penta-acetic acid. Aortography was unsuccessful despite repeated puncture attempts at lower dorsal and upper lumbar levels. Biopsy of the right kidney showed extensive cellular necrosis (figure). Aortic thrombosis affecting the renal arteries was diagnosed. He was maintained on peritoneal dialysis for 42 days, but this was stopped when urine output remained below $250 \mathrm{ml} /$ day.

Necropsy showed a small (67 g) fibrotic left kidney and a small (165 g) right kidney, not obviously infarcted. There was old thrombotic occlusion of the aorta extending above the renal arteries. The left renal artery was blocked by old thrombus and the right renal artery by more recent thrombus. There was severe coronary atheroma and considerable myocardial fibrosis.

\section{Comment}

The right renal artery thrombosis was almost certainly due to the fall in blood pressure caused by treatment. Because silent thrombosis of the abdominal aorta affecting the left renal artery had already occurred anuria resulted in this case. Antihypertensive treatment is not a previously reported cause of renal artery thrombosis. ${ }^{1}$ As both

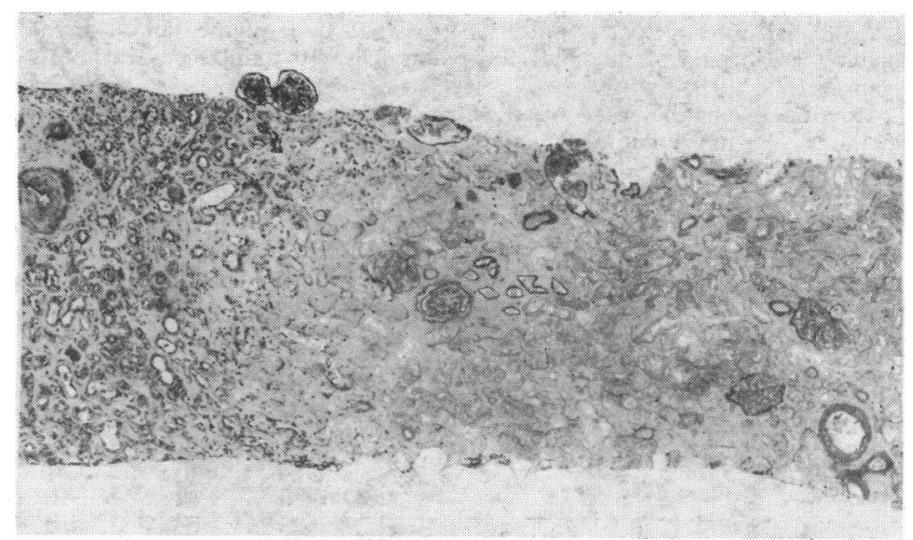

Renal biopsy specimen showing extensive cellular necrosis. Periodic-acidSchiff $\times 20$ (original magnification).

distal aortic thrombosis (Leriche's syndrome) ${ }^{2}$ and renal artery thrombosis ${ }^{3}$ may be clinically silent, however, thrombosis of a stenosed renal artery after antihypertensive treatment might easily occur unrecognised.

Distal aortic thrombosis increases the likelihood of stenosis or thrombosis of a renal artery, and we suggest that the femoral arteries should be palpated to detect Leriche's syndrome before antihypertensive treatment is started in patients with peripheral vascular disease. Although the state of the renal arteries in 1972 was not recorded, renal artery stenosis of some degree may well have been present. Reconstructive surgery in patients with hypertension due to renal artery stenosis improves renal function in patients somewhat younger than ours. ${ }^{4}$ Our patient shows that the choice between reconstructive surgery, balloon dilatation, drug treatment, and no treatment may be difficult in hypertensive patients with arterial stenosis. Certainly drugs must be used carefully in older patients. In our patient the serum atenolol concentration would have been raised by impaired renal excretion. ${ }^{5}$

${ }^{1}$ Montoliu J. Renal artery thrombosis: systemic contraceptive-induced or spontaneous? Ann Intern Med 1979;91:657.

2 Sabiston DC Jr. Disorders of the arterial system: In: Sabiston JC Jr, ed. Textbook of surgery. Philadelphia: W B Saunders, 1972:1939-42.

${ }^{3}$ Lessman RK, Johnson SF, Coburn JW, Kaufman JJ. Renal artery embolism. Clinical features and long-term follow-up of 17 cases. Ann Intern Med 1978;89:477-82.

4 Mackay A, Brown JJ, Lever AF, Robertson JIS. Reconstructive surgery versus nephrectomy in renal artery stenosis: comparison of effects on total and divided renal functions and on blood pressure. $\mathrm{Br} \mathrm{Med} \mathcal{F}$ $1980 ; 281$ : 1313-5.

${ }^{5}$ Sassard J, Pozet N, McAinsh J, Legheard J, Zeck P. Pharmacokinetics of atenolol in patients with renal impairment. Eur $\mathcal{F}$ Clin Pharmacol $1977 ; 12: 175-80$.

(Accepted 9 September 1982)

Royal Infirmary, Bradford BD9 6RJ

A B SHAW, MD, FRCP, consultant physician

$S \mathrm{~K}$ GOPALKA, MB, BS, senior house officer in general medicine

\section{Rastafarianism and the vegans syndrome}

Low serum vitamin $B_{12}$ concentrations are common in vegans. We report the first account of the syndrome in members of the Rastafarian cult, which started in Jamaica more than 40 years ago.

\section{Subjects, methods, and results}

Ten Rastafarian men aged 18 to 40 who had been vegans for from two to 20 years presented with evidence of vitamin $B_{12}$ deficiency. Eight had neurological manifestations ranging from paresthesiae to subacute combined degeneration. Five patients had gastrointestinal symptoms: glossitis in three, anorexia in two (cases 6 and 7 ; case 6 also had epigastric discomfort), and 
vomiting in one (case 9). One patient (case 3) had abdominal pain; one (case 8) had intermittent claudication; two had hyperpigmentation, of the palms (case 2) and of the soles and palms (case 10); and six were mildly jaundiced.

Routine haematological investigations were performed using standard methods. ${ }^{1}$ Serum vitamin $B_{12}$ and red cell folate concentrations were determined by microbiological methods, using Lactobacillus leishmanii and $L$ casei. In all but one case maximum reticulocyte response to $5 \mu \mathrm{g}$ vitamin $\mathbf{B}_{12}$ daily given parenterally (orally in case 2 ) was also measured. Absorption of $B_{12}$ was studied in six cases using the Schilling test ${ }^{2}$ (with $1 \mu \mathrm{g}$ radioactive $\left.B_{12}\right)$.
Requests for reprints should be addressed to Dr W N Gibbs. 1 Dacie JV, Lewis SM. Practical haematology. Edinburgh: Churchill
Livingstone, 1975 .

2 Schilling RF. Intrinsic factor studies; effect of gastric juice on urinary excretion of radioactivity after oral administration of radioactive vitamin B12. F Lab Clin Med 1953;42:860-6.

${ }^{3}$ Herbert V, Zalusky R. Inter-relations of vitamin $\mathrm{B} 12$ and folic acid $D$ metabolism: folic acid clearance studies. $\mathcal{F}$ Clin Invest 1962;41:1263-76. ( $^{\circ}$

4 Habib GG. Nutritional vitamin B12 deficiency among Hindus. Trop Geogr Med 1964;16:206-15.

Clinical and haematological features of 10 men studied

\begin{tabular}{|c|c|c|c|c|c|c|c|c|}
\hline $\begin{array}{l}\text { Case } \\
\text { No }\end{array}$ & Age & $\begin{array}{l}\text { Haemoglobin } \\
\text { concentration } \\
(\mathrm{g} / \mathrm{dl})\end{array}$ & $\begin{array}{l}\text { Vegan } \\
\text { diet } \\
(\mathrm{yr})\end{array}$ & $\begin{array}{c}\text { Serum } \\
\mathbf{B}_{12} \\
(\mathrm{ng} / \mathrm{l})\end{array}$ & $\begin{array}{l}\text { Plasma } \\
\text { folate } \\
(\mu \mathrm{g} / 1)\end{array}$ & $\begin{array}{l}\text { Red cell } \\
\text { folate } \\
(\mu \mathrm{g} / 1)\end{array}$ & $\begin{array}{l}\text { Therapeutic } \\
\text { response* }\end{array}$ & $\begin{array}{c}\text { Result of } \\
\text { Schilling } \\
\text { test }\end{array}$ \\
\hline $\begin{array}{r}1 \\
2 \\
3 \\
4 \\
5 \\
6 \\
7 \\
8 \\
9 \\
10\end{array}$ & $\begin{array}{l}23 \\
19 \\
23 \\
40 \\
23 \\
23 \\
18 \\
32 \\
22 \\
37\end{array}$ & $\begin{array}{r}13.7 \\
6.3 \\
3.3 \\
13.3 \\
3.0 \\
4.6 \\
9.5 \\
3.9 \\
4.7 \\
3.9\end{array}$ & $\begin{array}{c}2 \\
3 \\
5 \\
5 \\
5 \\
5 \\
6 \frac{1}{2} \\
7 \\
9 \\
20\end{array}$ & $\begin{array}{r}40 \\
70 \\
55 \\
10 \\
50 \\
105 \\
75 \\
\text { ND } \\
10 \\
130\end{array}$ & $\begin{array}{r}3.7 \\
4.8 \\
2.2 \\
2.4 \\
<1.0 \\
11.6 \\
12.5 \\
2.4 \\
18.0 \\
15.7\end{array}$ & $\begin{array}{c}87 \\
\text { ND } \\
50 \\
112 \\
\text { ND } \\
\text { ND } \\
176 \\
45 \\
\text { ND } \\
\text { ND }\end{array}$ & $\begin{array}{r}\text { ND } \\
9 \% \\
32 \% \\
2 \% \\
30 \% \\
32 \% \\
32 \% \\
17 \% \\
12 \% \\
21 \%\end{array}$ & $\begin{array}{l}\text { ND } \\
\text { ND } \\
\text { Normal } \\
\text { Normal } \\
\text { ND } \\
\text { Normal } \\
\text { Normal } \\
\text { ND } \\
\text { Normal } \\
\text { Normal }\end{array}$ \\
\hline rmal & & $13 \cdot 0-17 \cdot 5$ & & $180-1000$ & $2-20$ & $80-470$ & & \\
\hline
\end{tabular}

ND $=$ Not done

*Maximum reticulocyte count after parenteral vitamin $B_{12}$ treatment (see text) except case 2 , where vitamin $B_{12}$ was given orally.

Eight patients were found to have moderate or severe macrocytic anaemia. Two of the three patients with subacute combined degeneration were not anaemic. The bone marrow was megoblastic in all patients, and all showed normal or increased iron stores. Vitamin $B_{12}$ deficiency was confirmed as the cause of megaloblastosis in all cases by low serum vitamin $B_{12}$ concentrations, reticulocyte response, or both. The reticulocyte response was poor in two patients; one was anaemic, but there was no clearly identifiable cause for the poor response in the other. Both patients had low serum vitamin $B_{12}$ concentrations and their haemoglobin concentrations rose after further vitamin $B_{12}$ treatment, reaching the normal range in the patient who was originally anaemic. Low plasma or red cell concentrations, detected in three of the patients described here, have been described in patients with vitamin $B_{12}$ deficiency. ${ }^{3}$

Onset of symptoms from two to 20 years after the start of the vegan diet suggests a dietary cause of vitamin $B_{12}$ deficiency. Vitamin $B_{12}$ absorption was normal in the six patients who underwent the Schilling test: more than $15 \%$ of the test dose appeared in the urine within 24 hours in all patients tested. Four patients did not undergo the Schilling test: in one case (2) the response to oral cyanocobalamin suggested that his vitamin $B_{12}$ absorption was also normal; in the other three cases $(1,5$, and 8 ) other causes of vitamin $\mathrm{B}_{12}$ deficiency were excluded by the clinical features and appropriate laboratory investigations.

There was complete haematological response to parenteral cyanocobalamin treatment in all patients. One of the three patients with subacute combined degeneration recovered completely and another showed considerable improvement but had residual motor defects after several months of treatment. The third patient died after a myocardial infarct 11 days after admission.

\section{Comment}

These patients were all members of the Rastafarian cult, a religious sect that started in Jamaica in the 1930s and has steadily increased in popularity, especially during the past decade. It has attracted young men in particular and the ages and sex of our patients are therefore not surprising. In contrast, most of the patients described in a report of vitamin $\mathrm{B}_{12}$ deficiency in Hindus in. Trinidad ${ }^{4}$ - the only other territory in the region in which macrocytic megaloblastic anaemia due to dietary vitamin $\mathrm{B}_{12}$ deficiency has been reported-were older, and women were also affected.

Rastafarians are now found in most of the English-speaking territories in the Caribbean and also in Europe (particularly Britain), Canada, and the United States of America. Most are easily recognisable because of their distinctive hairstyle. The continued growth of the cult indicates that increasing attention should be paid to the possibility of the vegans syndrome in young men presenting with neurological disease, overt megaloblastic anaemia, or both. Education of the public is also important, and members of the cult should be encouraged to include milk products in their diets. Our patients were not very cooperative in taking oral vitamin $B_{12}$ or attending the clinic for vitamin $B_{12}$ injections, and we have found it difficult to persuade them to eat meat.
(Accepted 5 August 1982)

Haematology Division, Pathology Department, University of the West Indies, Kingston 7, Jamaica

MARIE CAMPBELL, MD, lecturer

W S LOFTERS, MB, FRCP(C), lecturer

W N GIBBS, MD, FRCPATH, reader

\section{Neurofibromatosis, phaeochromocytoma, and somatostatinoma}

The tetradecapeptide, somatostatin, occurs in many tissues, including $\overrightarrow{\vec{O}}$ the upper gastrointestinal tract. In the pancreas it is found in the DJ cell of the Islets of Langerhans. Cells containing somatostatin have? been found in various Islet-cell tumours. The first case of a tumouro producing somatostatin-like immunoreactivity and bioactivity was discovered incidentally during cholecystectomy. ${ }^{1}$ The first preoperative diagnosis of somatostatinoma was by Krejs et al in $1979^{2}$ and was suggested by the combination of diabetes mellitus, cholelithiasis, steatorrhoea, and an ampullary tumour.

\section{Case report}

A 49-year-old unmarried woman was seen in July 1981 complaining of weight loss, exertional dyspnoea, and night sweats for 18 months. She had increased appetite and was often awakened during the night by a desire for $\frac{D}{2}$ food. She had widespread non-familial neurofibromatosis and had been hypertensive for 15 years. She had chronic dyspeptic symptoms, and partial $N$ gastrectomy had been performed for duodenal ulcer 21 years previously. On examination she had hepatomegaly, a right hypochondrial mass, tremor $\omega$ of the hands, and sinus tachycardia. Her blood pressure was $200 / 110 \mathrm{Hg} \mathrm{mm}$. A provisional diagnosis of phaeochromocytoma was made.

\section{INVESTIGATIONS}

The 24-hour urinary 4-hydroxy-3-methoxymandelate concentration was $107 \mu \mathrm{mol}$ (normal range $3-38 \mu \mathrm{mol}$ ). Liver function tests showed an obstruc- $\overrightarrow{\mathbb{D}}$ tive pattern (serum alkaline phosphatase 3290 IU/1). Random blood sugar 9 estimations were normal. Intravenous pyelography showed hydronephrosis of the left kidney and renal angiography left renal artery stenosis and a vascular $\sigma$ mass above the right kidney. Ultrasonography indicated distension of the gall bladder, multiple gallstones, and dilatation of the biliary radicles. In addition, $\bigcirc$ a computed tomography scan showed a right suprarenal mass with the characteristics of a phaeochromocytoma. 